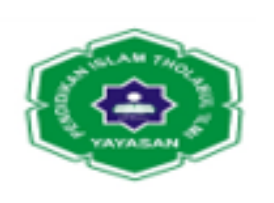

Jurnal Ilmiah METADATA

\title{
TINJAUAN TERHADAP TINDAK PIDANA BERDASARKAN UU RI NO. 7 TAHUN 1996 TENTANG PANGAN (Studi Kasus Perkara No. 54/Pid.B/2003/PN.Mdn)
}

\author{
Cut Nurita1), Muhammad Ridwan Lubis ${ }^{2)}$ \\ ${ }^{1)}$ STIH Benteng Huraba \\ 2)Universitas Muslim Nusantara Alwashliyah Medan \\ Email : cutnurita123@gmail.com \\ Email: muhammadridwanlubis76@ gmail.com
}

\begin{abstract}
ABSTRAK
Kegiatan atau proses produksi pangan untuk diedarkan atau diperdagangkan harus memenuhi ketentuan tentang sanitasi pangan, bahan tambahan pangan, residu cemaran, dan kemasan pangan. Hal lain yang patut diperhatikan oleh setiap orang yang memproduksi pangan adalah penggunaan metode tertentu dalam kegiatan atau proses produksi pangan yang memiliki kemungkinan timbulnya risiko yang dapat merugikan atau membahayakan kesehatan manusia, seperti rekayasa genetika atau iradiasi, harus dilakukan berdasarkan persyaratan tertentu.

Jenis penelitian penelitian ini menggunakan metode yuridis normatif. Dalam penulisan penelitian ini penulis menggunakan metode telaah pustaka (library research) untuk mentelaah data-data sekunder dan penelitian lapangan (field research) dengan melakukan penelitian ke Pengadilan Negeri Klas I A Medan.

Berdasarkan analisis data, maka diperoleh kesimpulan pengguna bahan pangan borax melampaui ambang batas sehingga membahayakan tindak pidana UU No. 7 Tahun 1996 Tentang Pangan dan Permenkes No. 722 Tahun 1988 adalah dengan menggunakan bahan borax untuk tambahan pangan yang dicampur dengan bakso dan setelah dicampur dengan borax lalu bakso dipasarkan atau dijual kepada konsumen. Pertanggungjawaban pelaku dalam perkara No. 54/Pid.B/PN.Mdn adalah dengan menjatuhkan hukum kepada pelaku yang menggunakan bahan pangan borax melampaui ambang batas karena perbuatan tersebut telah memenuhi unsur-unsur Pasal 10 ayat (1) Jo. Pasal 55 b UU No. 7 Tahun 1996 Tentang Pangan Jo. Pasal 3 ayat (1) Bab III Permenkes No. 722 Tahun 1988. Berdasarkan kesimpulan, maka disarankan memberantas atau mencegah mengedarkan bahan pangan yang mengandug zat kimia yang berbahaya bagi kesehatan dengan cara menghukum pelaku kejahatan mengedarkan sediaan farmasi tanpa izin dengan hukuman yang lebih berat. Masyarakat agar tidak segan-segan untuk melaporkan kepada kepolisian bila melihat adanya gejalagejala tidak baik yang dapat menjurus kepada atau ke arah terjadinya kriminalitas seperti mengedarkan bahan pangan yang mengandung zat atau bahan tambahan makanan yang melampaui batas yang ditetapkan agar dapat secara cepat mencegah terjadinya kejahatan ditengah-tengah masyarakat.
\end{abstract}

Kata Kunci : Tindak Pidana, UU RI No. 7 Tahun 1996 Tentang Pangan 


\section{Jurnal Ilmiah METADATA}

\section{PENDAHULUAN}

Setiap warga negara memiliki hak asasi manusia atas kesehatan, hidup sejahtera lahir dan batin, seperti ditegaskan dalam UUD 1945 Pasal 28H ayat (1) dan ayat (3). Mendapatkan bahan pangan yang sehat sesuai dengan kebutuhan merupakan hak asasi manusia dan salah satu unsur kesejahteraan yang harus diwujudkan sesuai dengan cita-cita bangsa Indonesia sebagaimana dimaksud dalam Pembukaan UUD 1945. Begitu pula penyediaan pangan yang baik dan berkualitas juga harus diwujudkan demi terjaminnya masyarakat yang sehat.

Ketidakpedulian para pelaku usaha terhadap bahan-bahan pangan yang membahayakan kesehatan dapat menimbulkan kerugian terhadap masyarakat tidak hanya terbatas pada proses produksi yang tidak memenuhi persyaratan registrasi, namun juga pada sistem penyalurannya tidak memiliki izin edar.

Munculnya produk makanan yang membahayakan kesehatan dan jiwa konsumennya, dalam pandangan hukum sebagai suatu perbuatan yang dilarang sebagaimana telah diatur dalam ketentuan perundang-undangan yang berlaku, baik dalam ketentuan UU No. 36 Tahun 2009 Tentang Kesehatan maupun yang terdapat dalam ketentuan UU No. 8 Tahun 1999 tentang Perlindungan Konsumen. Dalam undang-undang ini klausul pasal-pasalnya terdapat ketentuan yang mengatur tentang penerapan sanksi pidana terhadap para pelaku usaha yang terbukti melakukan pelanggaran pidana pengadaan, penyimpanan, penjualan makanan berbahaya tanpa izin dan obat tanpa izin edar yang proses pembuatannya tidak memenuhi standar registrasi yang ditentukan.

Atas dasar kerugian-kerugian baik fisik, sosial, maupun ekonomi dari pelanggaran pidana yang dilakukan oleh pelaku usaha tersebut, maka sangat beralasan untuk mengorganisasikan secara sistematis kebijakan kriminal (criminal policy) guna penanggulangan kejahatan tersebut. Kebijakan tersebut harus menggunakan secara berpasangan langkah-langkah yuridis maupun langkah-langkah non yuridis dalam bentuk-bentuk tindakan-tindakan pencegahan dalam rangka mengatasi kendala -kendala di atas. ${ }^{1}$

${ }^{1}$ J.E. Sahetapy, Bunga Rampai Viktimisasi, Eresco, Bandung, 2005, h. 97 


\section{Jurnal Ilmiah METADATA}

Dalam mewujudkan masyarakat yang adil dan makmur pemerintah wajib melindungi masyarakat dari penggunaan bahan pangan yang merugikan dan/atau membahayakan, melalui pengawasan makanan yang memenuhi standar dan persyaratan. Oleh karena itu, setiap kegiatan dan upaya untuk memenuhi standar keamanan, khasiat/manfaat dari bahan pangan, serta setiap kegiatan dan upaya untuk memenuhi standar keamanan dan mutu bagi masyarakat dilakukan berdasarkan asas kemanusiaan, keamanan, khasiat/manfaat, mutu, dan ketersediaan yang sangat penting artinya bagi pembentukan sumber daya manusia Indonesia yang sehat dan berdaya saing tinggi sehingga mampu berpartisipasi dalam pembangunan nasional.

Maraknya pemberitaan mengenai penggunaan formalin sebagai pengawet dalam bahan tambahan makanan mendorong Badan Pengawas Obat dan Makanan (BPOM) untuk melakukan investigasi dan penyelidikan laboratorium sehingga diketahui banyak produk ikan asin, tahu dan mie basah yang beredar di masyarakat dinyatakan mengandung formalin. ${ }^{2}$

Di Indonesia telah dibentuk suatu badan yang bertugas untuk mengawasi peredaran obat dan makanan, yakni Badan Pengawas Obat dan Makanan (BPOM). BPOM dibentuk berdasarkan Keputusan Presiden (Keppres) Nomor 166 Tahun 2000 jo Keppres Nomor 103 Tahun 2001 tentang Kedudukan, Tugas, Fungsi, Kewenangan, Susunan Organisasi dan Tata Kerja Lembaga Pemerintah Non Departemen (LPND) yang mengatur mengenai pembentukan lembagalembaga pemerintah nondepartemen. LPND adalah lembaga pemerintah pusat yang dibentuk untuk menjalankan tugas pemerintahan tertentu dari presiden serta bertanggung jawab langsung pada presiden. BPOM merupakan salah satu LPND yang mempunyai tugas yang terkait dengan pengawasan obat dan makanan.

Disisi lain, BPOM sebagai lembaga pemerintah non departemen berwenang untuk melakukan penyelidikan dan penyidikan terhadap indikasi perbuatan melawan hukum di bidang makanan. Namun demikian, mengingat bahwa tindak pidana penyalahgunaan formalin sebagai bahan pengawet dalam

${ }^{2}$ http://www.makanan mengandung formalin, .minihub.org/direito/txt/2003/22/10direito.html, diakses tanggal10 Januari 2013 


\section{Jurnal Ilmiah METADATA}

bahan tambahan makanan dikategorikan sebagai tindak pidana aduan absolut, maka investigasi dan penyelidikan laboratorium oleh BPOM barn dapat dilakukan apabila terdapat

pengaduan dan pihak-pihak yang merasa dirugikan.

\section{METODE PENELITIAN}

Penelitian ini tergolong sebagai penelitian hukum normatif. Data penelitian ini bersumber dari data sekunder yang bersumber dari bahan-bahan hukum, yang terdiri dari bahan hukum primer, sekunder dan tersier. Penelitian ini menggunakan pendekatan undang-undang dan pendekatan konseptual. Analisis data dalam penelitian ini menggunakan analisis data kualitatif.

\section{HASIL DAN PEMBAHASAN}

\section{A. Pengertian Tindak Pidana}

Perbuatan tindak pidana adalah perbuatan yang dilarang oleh suatu aturan hukum larangan mana disertai ancaman (sanksi) yang berupa pidana tertentu, bagi barangsiapa melanggar larangan tersebut. Dapat juga dikatakan bahwa perbuatan pidana adalah perbuatan yang oleh suatu aturan hukum dilarang diancam pidana, asal saja dimana pada saat itu diingat bahwa larangan ditujukan kepada perbuatan, (yaitu suatu keadaan atau kejadian yang ditimbulkan oleh kekuatan orang), sedangkan ancaman pidananya ditujukan kepada orang yang menimbulkannya kejadian itu.

Komariah E. Sapardjaja "Tindak Pidana adalah suatu perbuatan manusia yang memenuhi perumusan delik, melawan hukum dan pembuat bersalah melakukan perbuatan itu. ${ }^{7}$

Indriyanto Seno Adji menyatakan, "Tindak Pidana adalah perbuatan seseorang yang diancam pidana, perbuatannya bersifat melawan hukum, terdapat

${ }^{7}$ Komariah E. Sapardjaya, Ajaran Melawan Hukum Materiil dalam Hukum Pidana Indonesia, Studi Kasus Tentang Penerapan dan Perkembangannya dalam Yurisprudensi, Alumni, Bandung, 2002, h. 22 


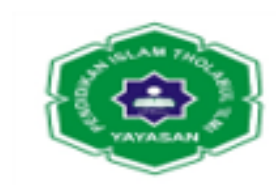

\section{Jurnal Ilmiah METADATA}

suatu kesalahan dan bagi pelakunya dapat dipertanggung jawabkan atas perbuatannya. $^{8}$

Dengan demikian dapat dipahami, bahwa sutau tindak pidana merupakan suatu tindakan yang dilarang atau di cela oleh masyarakat dan dilakukan oleh orang yang bersalah yang dapat dikenakan sanksi pidana. Unsur kesalahan atau pertanggung jawaban menjadi bagian pengertian tindak pidana.

A. Ridwan Halim, menyebut tindak pidana sebagai delik yaitu : suatu perbuatan atau tindakan yang dilarang dan diancam dengan hukuman oleh Undang - undang (pidana). ${ }^{9}$ Dari apa yang dikatakan oleh A Ridwan Halim, jelas agar suatu perbuatan dapat dikatakan sebagai tindak pidana, maka perbuatan tersebut harus telah diatur dalam suatu peraturan perundang - undangan serta diancam dengan hukuman.

Berkaitan dengan pemahaman tindak pidana tersebut di atas Moeljatno, mengemukakan beberapa unsur-unsur untuk adanya suatu tindak pidana atau perbuatan pidana yaitu :

1. Adanya subyek hukum, yang dapat dijadikan subyek hukum hanyalah orang

2. Adanya perbuatan yang dilarang, perbuatan yang dilakukan sesuai dengan rumusan delik.

3. Bersifat melawan hukum yaitu :

a. Melawan hukum formal artinya apabila perbuatan yang dilakukan sebelumnya telah diatur dalam und ang-undang.

b. Melawan hukum material artinya apabila perbuatan yang dilakukan melanggar aturan atau nilai-nilai yang hidup dalam masyarakat harus adanya kesalahan. Kesalahan yang dimaksud adalah pencelaan dari masyarakat apabila melakukan hal tersebut sehingga adanya hubungan batin antara pelaku dengan kejadian yang nantinya akan menimbulkan suatu akibat. Kesalahan itu sendiri dapat dibagi 2 yaitu kesengajaan/dolus dan kealpaan.

4. Harus dapat dipertanggung jawabkan

5. Sesuai dengan waktu, tempat dan keadaan. ${ }^{10}$

\footnotetext{
${ }^{8}$ Indriyanto Seno Adji, Korupsi dan Hukum Pidana, PT. Raja Grafindo, Jakarta, 2002, h. 155

${ }^{9}$ Ridwan Halim, Hukum Pidana dalam Tanya Jawab, Alumni, Bandung, 1986, h.52

${ }^{10}$ Moelyatno, Perbuatan Pidana dan Pertanggungjawaban Dalam Hukum Pidana, Bina Aksara, Jakarta, 1983, h, 11
} 


\section{Jurnal Ilmiah METADATA}

Dari hal tersebut terlihat bahwa kesalahan adalah faktor penentu pertanggung jawaban pidana karenanya tidak sepatutnya menjadi bagian definisi tindak pidana. Hal ini Nampak sebagaimana di katakana Moeljatno, apakah Inkonkreto yang melakukan perbuatan tadi sungguh - sungguh di jatuhi pidana atau tidak. Itu sudah di luar arti perbuatan pidana. Artinya apakah yang melakukan tindak pidana tersebut kemudian dipertanggungjawabkan atas perbuatannya sudah diluar kontek penegrtian tindak pidana. ${ }^{11}$

Moeljatno mengatakan tindak pidana adalah perbuatan yang dilarang dan diancam dengan pidana barang siapa yang melakukan. Di lain kesempatan juga beliau mengatakan, suatu tindak pidana adalah perbuatan atau omisi yang dilarang oleh hukum untuk melindungi masyarakat, dan dapat dipidana berdasarkan prosedur hukum yang berlaku. Dalam definisi-definisi tersebut, unsure keslahan telah dikeluarkan, sehingga tindak pidana pada hakikatnya adalah "perbuatan. saja. Perbuatan disini berisi kelakuan dan kejadian yang ditimbulkan oleh kelakukan atau kelakuan dan akibatnya. ${ }^{12}$

Kelakuan juga terdiri dari melakukan sesuatu (komisi) dan tidak melakukan sesuatu (omisi). Dengan demikian, tindak pidana merupakan perbuatan melakukan sesuatu, perbuatan tidak melakukan sesuatu, dan menimbulkan akibat, yang dilarang oleh undang-undang.

\section{B. Tinjauan Tentang Pangan}

Pangan menurut Undang Undang No. 7 Tahun 1996 Tentang Pangan adalah segala sesuatu yang berasal dari sumber hayati dan air, baik yang diolah maupun yang tidak diolah, yang diperuntukkan sebagai makanan atau minuman bagi konsumsi manusia. Termasuk didalamnya adalah tambahan pangan, bahan baku pangan, dan bahan lain yang digunakan dalam penyiapan, pengolahan, dan atau pembuatan makanan atau minuman.

Berdasarkan cara perolehannya, pangan dibedakan menjadi 3 (tiga) yaitu :

11 Chairul Huda, Dari Tiada Pidana Tanpa Kesalahan Menuju Kepada Tiada Pertanggungjawaban Pidana Tanpa Kesalahan. Prenada Media Group, Jakarta, 2008, h. 27

${ }^{12}$ Moelyatno, Asas-asas Hukum Pidana, Bina Aksara, Jakarta, 1987, h 155 


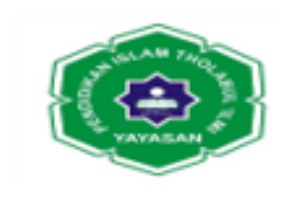

\section{Jurnal Ilmiah METADATA}

a. Pangan segar yaitu pangan yang belum mengalami pengolahan. Pangan segar dapat dikonsumsi langsung atau tidak langsung, yakni dijadikan bahan baku pengolahan pangan.

b. Pangan olahan adalah makanan atau minuman hasil proses pengolahan dengan cara atau metode tertentu, dengan atau tanpa bahan tambahan. Contoh : the manis, nasi, pisang goreng dan sebagainya. Pangan olahan bisa dibedakan lagi menjadi pangan olahan siap saji dan tidak saji.

c. Pangan olahan siap saji adalah makanan dan minuman yang sudah diolah dan siap disajikan di tempat usaha atau di luar tempat usaha atau dasar pesanan.

d. Pangan olahan tidak siap saji adalah makanan atau minuman yang sudah mengalami proses pengolahan, akan tetapi masih memerlukan tahapan pengolahan lanjutan untuk dapat dimakan atau diminum.

e. Pangan olahan tertentu adalah pangan olahan yang diperuntukkan bagi kelompok tertentu dalam upaya memelihara dan meningkatkan kualitas kesehatan. Contoh ekstrak tanaman mahkota dewa untuk diabetes melitus, susu rendah lemak untuk orang yang menjalankan diet rendah lemak, dan sebagainya. ${ }^{16}$

Pangan sebagai kebutuhan dasar manusia yang pemenuhannya merupakan hak asasi setiap rakyat Indonesia harus senantiasa tersedia cukup setiap waktu, aman, bermutu, bergizi, dan beragam dengan harga yang terjangkau oleh daya beli masyarakat. Untuk mencapai semua itu, perlu diselenggarakan suatu sistem pangan yang memberikan perlindungan, baik bagi pihak yang memproduksi maupun yang mengkonsumsi pangan, serta tidak bertentangan dengan keyakinan masyarakat.

Sumber daya manusia yang berkualitas selain merupakan unsur terpenting yang perlu memperoleh prioritas dalam pembangunan, juga sebagai salah satu faktor penentu keberhasilan pembangunan. Peningkatan kualitas sumber daya manusia sangat ditentukan, antara lain, oleh kualitas pangan yang dikonsumsinya.

Kegiatan atau proses produksi pangan untuk diedarkan atau diperdagangkan harus memenuhi ketentuan tentang sanitasi pangan, bahan tambahan pangan, residu cemaran, dan kemasan pangan. Hal lain yang patut diperhatikan oleh setiap orang yang memproduksi pangan adalah penggunaan metode tertentu dalam kegiatan atau proses produksi pangan yang memiliki

${ }^{16}$ Romli Atmasasmita, Bentuk-Bentuk Tindak Pidana Yang Dilakukan Oleh Produsen Pada Era Perdagangan Bebas, Mandar Madju, Bandung, 2000, h.82 


\section{Jurnal Ilmiah METADATA}

kemungkinan timbulnya risiko yang dapat merugikan atau membahayakan kesehatan manusia, seperti rekayasa genetika atau iradiasi, harus dilakukan berdasarkan persyaratan tertentu.

Setiap orang yang memproduksi pangan untuk diperdagangkan perlu memperhatikan ketentuan mengenai mutu dan gizi pangan yang ditetapkan. Pangan tertentu yang diperdagangkan dapat diwajibkan untuk terlebih dahulu diperiksa di laboratorium sebelum diedarkan. Dalam upaya meningkatkan kandungan gizi pangan olahan tertentu, Pemerintah berwenang untuk menetapkan persyaratan tentang komposisi pangan tersebut.

Setiap produsen dibebani tanggung jawab, terutama apabila pangan yang diproduksinya menyebabkan baik kerugian pada kesehatan manusia maupun kematian orang yang mengkonsumsi pangan tersebut. Dalam hal itu, Undangundang ini secara spesifik mengatur tanggung jawab industri pangan untuk memberikan ganti rugi kepada pihak yang dirugikan. Di samping tanggung jawab untuk memberikan ganti rugi sebagaimana dimaksud di atas, Undang-undang ini juga menetapkan ketentuan sanksi lainnya, baik yang bersifat administrative maupun pidana terhadap para pelanggarnya.

Dalam kegiatan perdagangan pangan, masyarakat yang mengkonsumsi perlu diberikan sarana yang memadai agar memperoleh informasi yang benar dan tidak menyesatkan. Sehubungan dengan hal tersebut, perlu ditetapkan ketentuan mengenai label dan iklan tentang pangan. Dengan demikian, masyarakat yang mengkonsumsi pangan dapat mengambil keputusan berdasarkan informasi yang akurat sehingga tercipta perdagangan pangan yang jujur dan bertanggung jawab, yang pada gilirannya menumbuhkan persaingan yang sehat di kalangan para pengusaha pangan. Khusus menyangkut label atau iklan tentang pangan yang mencantumkan pernyataan bahwa pangan telah sesuai dengan persyaratan atau kepercayaan tertentu, maka orang yang membuat pernyataan tersebut bertanggung jawab terhadap kebenaran pernyataan dimaksud.

Pengusaha kecil di bidang pangan pada tahap-tahap awal mungkin mengalami kesulitan untuk memenuhi keseluruhan persyaratan yang ditetapkan oleh Undang-undang ini. Untuk mengatasi hal ini, diperlukan pembinaan secara 


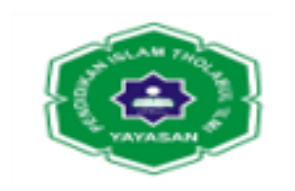

\section{Jurnal Ilmiah METADATA}

berkesinambungan agar pengusaha kecil tersebut dapat memenuhi persyaratan keamanan, mutu, dan gizi pangan. Berkenaan dengan itu, pelaksanaan ketentuanketentuan tersebut dilakukan secara bertahap.

Ketentuan mengenai keamanan, mutu, dan gizi pangan, serta label dan iklan pangan tidak hanya berlaku bagi pangan yang diproduksi dan atau diedarkan di wilayah Indonesia, tetapi juga bagi pangan yang dimasukkan ke dalam wilayah Indonesia. Dalam hal-hal tertentu bagi produksi pangan nasional yang akan diedarkan di luar negeri, diberlakukan ketentuan yang sama.

Sebagai komoditas dagang, pangan memiliki peranan yang sangat besar dalam peningkatan citra pangan nasional di dunia internasional dan sekaligus penghasil devisa. Oleh karena itu, produksi pangan nasional harus mampu memenuhi standar yang berlaku secara internasional dan memerlukan dukungan perdagangan pangan yang dapat memberi peluang bagi pengusaha di bidang pangan, baik yang besar, menengah maupun kecil, untuk mendukung pertumbuhan ekonomi.

Pengaturan mengenai pangan juga diarahkan untuk mewujudkan ketahanan pangan yang mencakup ketersediaan dan cadangan pangan, serta terjangkau sesuai dengan kebutuhan konsumsi masyarakat. Pemerintah bersama masyarakat perlu memelihara cadangan pangan nasional. Di samping itu, Pemerintah dapat mengendalikan harga pangan tertentu, baik untuk tujuan stabilisasi harga maupun untuk mengatasi keadaan apabila terjadi kekurangan pangan atau keadaan darurat lainnya.

\section{Penggunaan Bahan Pangan Borax Melampaui Ambang Batas Sehingga Membahayakan Kesehatan Masyarakat Menurut UU No. 7 Tahun 1996 Tentang Pangan.}

Kegiatan atau proses produksi pangan untuk diedarkan atau diperdagangkan harus memenuhi ketentuan tentang sanitasi pangan, bahan tambahan pangan, residu cemaran, dan kemasan pangan. Hal lain yang patut diperhatikan oleh setiap orang yang memproduksi pangan adalah penggunaan metode tertentu dalam kegiatan atau proses produksi pangan yang memiliki 


\section{Jurnal Ilmiah METADATA}

kemungkinan timbulnya risiko yang dapat merugikan atau membahayakan kesehatan manusia, seperti rekayasa genetika atau iradiasi, harus dilakukan berdasarkan persyaratan tertentu.

Setiap orang yang memproduksi pangan untuk diperdagangkan perlu memperhatikan ketentuan mengenai mutu dan gizi pangan yang ditetapkan. Pangan tertentu yang diperdagangkan dapat diwajibkan untuk terlebih dahulu diperiksa di laboratorium sebelum diedarkan. Dalam upaya meningkatkan kandungan gizi pangan olahan tertentu, Pemerintah berwenang untuk menetapkan persyaratan tentang komposisi pangan tersebut.

Setiap orang yang memproduksi pangan untuk diedarkan perlu dibebani tanggung jawab, terutama apabila pangan yang diproduksinya menyebabkan baik kerugian pada kesehatan manusia maupun kematian orang yang mengkonsumsi pangan tersebut. Dalam hal itu, Undang-undang ini secara spesifik mengatur tanggung jawab industri pangan untuk memberikan ganti rugi kepada pihak yang dirugikan. Di samping tanggung jawab untuk memberikan ganti rugi juga ditentukan sanksi lainnya, baik yang bersifat administratif maupun pidana terhadap para pelanggarnya.

Dalam kegiatan perdagangan pangan, masyarakat yang mengkonsumsi perlu diberikan sarana yang memadai agar memperoleh informasi yang benar dan tidak menyesatkan. Sehubungan dengan hal tersebut, perlu ditetapkan ketentuan mengenai label dan iklan tentang pangan. Dengan demikian, masyarakat yang mengkonsumsi pangan dapat mengambil keputusan berdasarkan informasi yang akurat sehingga tercipta perdagangan pangan yang jujur dan bertanggung jawab, yang pada gilirannya menumbuhkan persaingan yang sehat di kalangan para pengusaha pangan. Khusus menyangkut label atau iklan tentang pangan yang mencantumkan pernyataan bahwa pangan telah sesuai dengan persyaratan atau kepercayaan tertentu, maka orang yang membuat pernyataan tersebut bertanggung jawab terhadap kebenaran pernyataan dimaksud.

Ketentuan mengenai keamanan, mutu, dan gizi pangan, serta label dan iklan pangan tidak hanya berlaku bagi pangan yang diproduksi dan atau diedarkan di wilayah Indonesia, tetapi juga bagi pangan yang dimasukkan ke dalam wilayah 


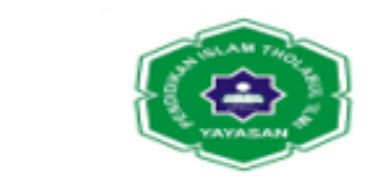

\section{Jurnal Ilmiah METADATA}

Indonesia. Dalam hal-hal tertentu bagi produksi pangan nasional yang akan diedarkan di luar negeri, diberlakukan ketentuan yang sama.

Sebagai komoditas dagang, pangan memiliki peranan yang sangat besar dalam peningkatan citra pangan nasional di dunia internasional dan sekaligus penghasil devisa. Oleh karena itu, produksi pangan nasional harus mampu memenuhi standar yang berlaku secara internasional dan memerlukan dukungan perdagangan pangan yang dapat memberi peluang bagi pengusaha di bidang pangan, baik yang besar, menengah maupun kecil, untuk mendukung pertumbuhan ekonomi.

Sekarang ini sudah banyak sekali bahan kimia dan berbagai campurancampuran lain dibuat dan diciptakan untuk membuat pekerjaan manusia dalam membuat makanan lebih efektif dan efisien. Tetapi di samping untuk makanan dibuat juga bahan kimia untuk pembuatan kebutuhan lain. Di mana bahkan kimia tersebut tidak boleh dipergunakan dalam pembutan makanan dan dapat berakibat fatal.

Boraks adalah bahan kimia yang digunakan sebagai pengawet kayu, antiseptik kayu dan pengontrol kecoa. Bahan kimia tersebut memang berguna jika digunakan sesuai fungsinya, tetapi menjadi sangat berbahaya bila digunakan dalam pembuatan pangan. Di mana pangan itu merupakan segala sesuatu yang menjadi bahan makanan manusia. Dan akibat dari penggunaan bahan-bahan kimia tersebut bisa jadi sngatlah fatal, dari kanker bisa menyebabkan kematian.

Boraks merupakan garam natrium yang banyak digunakan diberbagai industri non pangan, khususnya industri kertas, gelas, pengawet kayu da keramik. Boraks biasa berupa sebuk Kristal putih, tidak berbau, mudah larut dalam air, tetapi boraks tidak dapat larut dalam alkohol. Boraks biasa digunakan sebagai pengawet dan antiseptic kayu. Daya pengawet yang kuatdalam boraks berasal dari kandungan asam borat didalamnya.

Menurut Peraturan Menteri Kesehatan Republik Indonesia Nomor 1168/MENKES/PER/X/1999 Tentang Perubahan Atas Peraturan Menteri Kesehatan Nomor 722/MENKES/PER/IX/1988 Tentang Bahan Tambahan 


\section{Jurnal Ilmiah METADATA}

Makanan bahwa penggunaan kalium bromat dalam makanan dan minuman dapat membahayakan kesehatan karena bersifat karsinogenik, oleh karena itu perlu dilarang penggunaannya tetapi penggunaan kalium bromat sebagai bahan tambahan makanan berdasarkan Peraturan Menteri Kesehatan Nomor 722/Menkes/Per/IX/1988 masih diperbolehkan dalam batas-batas yang diizinkan.

Adapun kriteria pangan yang illegal adalah :

1. Izi edar palsu.

2. Tidak memiliki nomor registrasi.

3. Substandar atau makanan yang kandungannya tidak sesuai dengan seharusnya.

4. Pangan impor yang masuk secara ilegal

5. Makanan yang izin edarnya dibekukan tetapi masih tetap beredar. ${ }^{22}$

Tindak pidana mengedarkan pangan tanpa izin edar yang kerap terjadi dalam lingkungan masyarakat akan mewujudkan moral rendah, diakibatkan tekanan ekonomi sehingga menimbulkan reaksi-reaksi., atau juga dari kebiasaan jiwa seseorang yang mengalami kelainan jiwa. Sering sekali suatu kejahatan khususnya kasus mengedarkan pangan tanpa izin edar, dimungkinkan karena ada kesempatan dan niat yang telah direncanakan. ${ }^{23}$

Bahan tambahan yang dilarang melalui Permenkes No. 722/Menkes/Per/IX/88 adalah : Asam borat, Asam salisilat, Dietilpirokarbonat, Dulsin, Kalium klorat, Kloramfenol, Minyak nabati yang dibrominasi, Nitrofurazon, dan Formalin.

Asam borat atau Boraks (boric acid) merupakan zat pengawet berbahaya yang tidak dizinkan digunakan sebagai campuran bahan makanan. Boraks adalah senyawa berbentuk kristal putih, tidak berbau, dan stabil pada suhu dan tekanan normal. Dalam air, boraks berubah menjadi natrium hidroksida dan asam borat.

Asam borat sering digunakan dalam dunia pengobatan dan kosmetika. Misalnya larutan asam borat dalam air digunakan sebagai obat cuci mata dan dikenal sebagai boorwater. Asam borat juga digunakan sebagai obat kumur,

${ }^{22}$ Hasil Wawancara Dengan H. Ramli Darasah Hakim Pengadilan Negeri Klas I A Medan tanggal 25 April 2013

${ }^{23}$ Hasil Wawancara Dengan H. Ramli Darasah Hakim Pengadilan Negeri Klas I A Medan tanggal 25 April 2013 


\section{Jurnal Ilmiah METADATA}

semprot hidung, dan salep luka kecil. Namun, bahan ini tidak boleh diminum atau digunakan pada luka luas, karena beracun ketika terserap masuk dalam tubuh. Berikut beberapa pengaruh boraks pada kesehatan :

1. Tanda dan gejala akut : Muntah-muntah, diare, konvulusi dan depresi SSP (Susunan Syaraf Pusat).

2. Tanda dan gejala kronis : Nafsu makan menurun, gangguan pencernaan, gangguan SSP ( bingung dan bodoh), anemia, rambut rontok, dan kanker.

Boraks akan berguna dengan positif bila memang digunakan sesuai dengan seharusnya, tetapi kedua bahan itu tidak boleh dijadikan sebagai pengawet makanan karena bahan-bahan tersebut sangat berbahaya, seperti telah diuraikan diatas pengaruhnya terhadap kesehatan. Walaupun begitu, karena ingin mencari keuntungan sebanyak-banyaknya, banyak produsen makanan yang tetap menggunakan kedua bahan ini dan tidak meperhitungkan bahayanya.

Pada umunya, alasan para produsen menggunakan boraks sebagai bahan pengawet makanan adalah karena kedua bahan ini mudah digunakan dan mudah didapat, karena harganya relatif murah dibanding bahan pengawet lain yang tidak berpengaruh buruk pada kesehatan. Selain itu, boraks merupakan senyawa yang bisa memperbaiki tekstur makanan sehingga menghasilkan rupa yang bagus, misalnya bakso dan kerupuk. Beberapa contoh makanan yang dalam pembuatannya sering menggunakan boraks dan formalin adalah bakso, kerupuk, ikan, tahu, mie, dan juga dagig ayam.

Maraknya peredaran bahan pangan tanpa izin edar berdampak buruk bagi kesehatan masyarakat. Pelaku seakan-akan tidak menghiraukan akibat yang ditimbulkan dari tindakan pemalsuan yang mereka lakukan. ${ }^{24}$

Dalam upaya menanggulangi kecenderungan meningkatkan praktek kejahatan mengedarkan bahan pangan tanpa izin di samping dilakukan penindakan secara tegas terhadap pelaku kejahatan tersebut oleh aparat penegak

${ }^{24}$ Hasil Wawancara Dengan H. Ramli Darasah Hakim Pengadilan Negeri Klas I A Medan tanggal 25 April 2013 


\section{Jurnal Ilmiah METADATA}

hukum juga mutlak diperlukan peran serta aktif tokoh-tokoh agama, pemuka masyarakat, tokoh-tokoh adat dan pakar pendidik. ${ }^{25}$

Langkah-langkah atau usaha-usaha yang dilakukan baik secara operasional maupun konsepsional dalam mengatasi peredaran bahan pangan tanpa izin edar adalah :

1. Memberikan sanksi hukuman yang maksimal kepada pelaku kejahatan mengedarkan bahan pangan tanpa izin edar ataupun yang membantunya sesuai dengan ketentuan hukum yang berlaku.

2. Sesuai dengan cita-cita penegakan hukuman kita serta mempertimbangkan perkembangan masyarakat maka pendekatan hukum dengan pendekatan yurid is sudah tidak memadai lagi, pendekatan yuridis sebagai pendekatan utama dalam penegakan hukum perlu diimbangi dengan kekuatan sosio politik dan sosio kultural :

a. Pendekatan sosio yuridis yaitu dalam penegakan hukum secara tepat dan benar sesuai keyakinan.

b. Pendekatan sosio politik yaitu dalam penegakan hukum dimaksudkan untuk mewujudkan ketertiban, stabilitas dan kondisi yang diperlukan bagi kelangsungan pembangunan nasional serta kokohnya persatuan dan kesatuan bangsa.

c. Pendekatan sosio kultural dalam penegakan hukum berarti bahwa nilai-nilai yang hidup dalam masyarakat sehingga rasa keadilan masyarakat lebih terpenuhi yang lebih jauh akan meningkatkan kepercayaan dan dukungan masyarakat terhadap penegak hukum. ${ }^{26}$

a. Pertanggungjawaban Pelaku Dalam Perkara No. 54/Pid.B/PN.Mdn

Kejahatan yang semakin meningkat dan sering terjadi dalam masyarakat merupakan hal yang sangat diperhatikan, sehingga mengundang pemerintah (negara) sebagai pelayan, pelindung masyarakat untuk menanggulangi meluasnya dan bertambahnya kejahatan yang melanggar nilai-nilai maupun norma-norma ${ }^{27}$ yang hidup dan berlaku didalam suatu masyarakat sehingga kejahatan tersebut oleh negara dijadikan sebagai perbuatan pidana untuk tindak pidana. Hukum pidana merupakan sarana yang penting dalam penanggulangan kejahatan atau mungkin sebagai obat dalam memberantas kejahatan yang meresahkan dan merugikan masyarakat pada umunya dan korban pada khususnya.

${ }^{25}$ Hasil Wawancara Dengan H. Ramli Darasah Hakim Pengadilan Negeri Klas I A Medan tanggal 25 April 2013

${ }^{26}$ Hasil Wawancara Dengan H. Ramli Darasah Hakim Pengadilan Negeri Klas I A Medan tanggal 25 April 2013

${ }^{27}$ Adami Chazawi. Op.Cit. h.19 


\section{Jurnal Ilmiah METADATA}

Penanggulangan kejahatan tersebut dapat dilakukan secara preventif (pencegahan) dan refresif (penindakan). Bentuk penanggulangan tersebut dengan diterapkannya sanksi terhadap pelaku tindak pidana, sanksi pidana merupakan alat atau sarana terbaik yang tersedia, yang kita miliki untuk menghadapi ancamanancaman dari bahaya. Sanksi pidana suatu ketika merupakan penjamin yang utama/terbaik dan suatu etika merupakan pengancaman yang utama dari kebebasan manusia.

Pertanggungjawaban pidana dalam istilah asing tersebut juga dengan teorekenbaardheid atau criminal responsibility yang menjurus kepada pemidanaan petindak dengan maksud untuk menentukan apakah seseorang terdakwa atau tersangka dipertanggungjawabkan atas suatu tindakan pidana yang terjadi atau tidak. ${ }^{28}$

Untuk dapat dipidananya si pelaku, disyaratkan bahwa tindak pidana yang dilakukannya itu memenuhi unsur-unsur yang telah ditentukan dalam Undangundang. Dilihat dari sudut terjadinya tindakan yang dilarang, seseorang akan dipertanggungjawabkan atas tindakan-tindakan tersebut, apabila tindakan tersebut melawan hukum serta tidak ada alasan pembenar atau peniadaan sifat melawan hukum untuk pidana yang dilakukannya. Dan dilihat dari sudut kemampuan bertanggungjawab maka hanya seseorang yang mampu bertanggungjawab yang dapat dipertanggungjawabkan atas perbuatannya. Tindak pidana jika tidak ada kesalahan adalah merupakan asas pertanggungjawaban pidana, oleh sebab itu dalam hal dipidananya seseorang yang melakukan perbuatan sebagaimana yang telah diancamkan, ini tergantung dari soal apakah dalam melakukan perbuatan ini dia mempunyai kesalahan.

Berdasarkan hal tersebut maka pertanggung jawaban pidana atau kesalahan menurut hukum pidana, terdiri atas tiga syarat yaitu:

1. Dapat dipertanggungjawabkan kepada si pembuat atau kemampuan bertanggungjawab dari si pembuat.

${ }^{28}$ Pertanggungjawaban Pidana (Perspektif Hukum Islam dan Hukum Positif)", melalui http://www.kompas.wordpress.com diakses tanggal6 Mei 2013 


\section{Jurnal Ilmiah METADATA}

2. Ada hubungan tertentu dalam batin orang yang berbuat, baik dalam bentuk kesengajaan maupun kealpaan.

3. Tidak ada dasar alasan yang menghapus pertanggungjawaban si pembuat atau tidak ada alasan penghapusan kesalahan. ${ }^{29}$

Kemampuan untuk membeda-bedakan antara perbuatan yang baik dan yang buruk, adalah merupakan faktor akal (intelektual factor) yaitu dapat membedakan perbuatan yang diperbolehkan dan yang tidak. Dan kemampuan untuk menentukan kehendaknya menurut keinsyafan tentang baik buruknya perbuatan tersebut adalah merupakan faktor perasaan (volitional factor) yaitu dapat menyesuaikan tingkah lakunya dengan keinsyafan atas mana yang diperbolehkan dan mana yang tidak. Sebagai konsekuensi dari dua hal tadi maka tentunya orang yang tidak mampu menentukan kehendaknya menurut keinsyafan tentang baik buruknya perbuatan, dia tidak mempunyai kesalahan kalau melakukan tindak pidana, orang demikian itu tidak dapat dipertanggung jawabkan.

Oleh karena kemampuan bertanggung jawab merupakan unsur kesalahan, maka untuk membuktikan adanya kesalahan unsur tadi harus dibuktikan lagi. Mengingat hal ini sukar untuk dibuktikan dan memerlukan waktu yang cukup lama, maka unsur kemampuan bertanggungjawab dianggap diam-diam selalu ada karena pada umumnya setiap orang normal bathinnya dan mampu bertanggung jawab, kecuali kalau ada tanda-tanda yang menunjukkan bahwa terdakwa mungkin jiwanya tidak normal. Dalam hal ini, hakim memerintahkan pemeriksaan yang khusus terhadap keadaan jiwa terdakwa sekalipun tidak diminta oleh pihak terdakwa. Jika hasilnya masih meragukan hakim, itu berarti bahwa kemampuan bertanggungjawab tidak berhenti, sehingga kesalahan tidak ada dan pidana tidak dapat dijatuhkan berdasarkan asas tidak dipidana jika tidak ada kesalahan.

Kemampuan bertanggung jawab terdapat dalam Pasal 44 ayat (1) KUHP yang berbunyi : "Barangsiapa melakukan perbuatan yang tidak dapat 


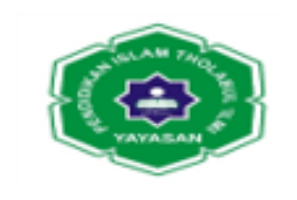

\section{Jurnal Ilmiah METADATA}

dipertanggung jawabkan kepadanya karena jiwanya cacat dalam pertumbuhan atau terganggu karena cacat, tidak dipidana."

Kalau tidak dipertanggungjawabkan itu disebabkan hal lain, misalnya jiwanya tidak normal dikarenakan dia masih muda, maka pasal tersebut tidak dapat dikenakan. Apabila hakim akan menjalankan Pasal 44 KUHP, maka sebelumnya harus memperhatikan apakah telah dipenuhi dua syarat sebagai berikut :

1. Apabila si pembuat tidak ada kebebasan untuk memilih antara berbuat atau tidak berbuat mengenap apa yang dilarang atau diperintahkan oleh undang-undang.

2. Apabila si pembuat berada dalam suatu keadaan yang sedemikian rupa, sehingga dia tidak dapat menginsyafi bahwa perbuatannya itu bertentangan dengan hukum dan tidak dapat menentukan akibat perbuatannya. ${ }^{30}$

Untuk menentukan adanya pertanggung jawaban, seseorang pembuat dalam melakukan suatu tindak pidana harus ada "sifat melawan hukum" dari tindak pidana itu, yang merupakan sifat terpenting dari tindak pidana. Tentang sifat melawan hukum apabila dihubungkan dengan keadaan psikis (jiwa) pembuat terhadap tindak pidana yang dilakukannya dapat berupa "kesengajaan" (opzet) atau karena "kelalaian" (culpa). Akan tetapi kebanyakan tindak pidana mempunyai unsur kesengajaan bukan unsur kelalaian. Hal ini layak karena biasanya, yang melakukan sesuatu dengan sengaja.

Menurut teori hukum pidana Indonesia kesengajaan itu ada tiga macam, yaitu:

a. Sengaja sebagai maksud (opzet als oogmerk).

Bahwa dengan kesengajaan yang bersifat maksud, si pelaku dapat dipertanggung jawabkan dan mudah dapat dimengerti oleh khalayak ramai. Apabila kesengajaan seperti ini ada pada suatu tindak pidana, si pelaku pantas dikenakan hukuman pidana. Karena dengan adanya kesengajaan yang bersifat tujuan ini, berarti si pelaku benar-benar menghendaki mencapai suatu akibat yang menjadi pokok alasan diadakannya ancaman hukuman ini.

b. Sengaja dengan kesadaran kemungkinan sekali terjadi (opzet met beewustheid van zekerheid of noodzakelijkheid).

30 Adami Chazawi.Op.Cit. h.20 


\section{Jurnal Ilmiah METADATA}

Kesengajaan ini ada apabila si pelaku, dengan perbuatannya tidak bertujuan untuk mencapai akibat yang menjadi dasar dari delik, tetapi ia tahu benar bahwa akibat itu pasti akan mengikuti perbuatan itu.

c. Sengaja dengan kesalahan kemungkinan sekali terjadi (opzer met waarschijnlijkheidsvewustzijn).

Kesengajaan ini yang terang-terang tidak disertai bayangan suatu kepastian akan terjadi akibat yang bersangkutan, melainkan hanya dibayangkan suatu kemungkinan belaka akan akibat itu. ${ }^{31}$

Mengenai kealpaan karena merupakan bentuk dari kesalahan yang menghasilkan dapat dimintai pertanggung jawaban atas perbuatan seseorang yang dilakukannya, seperti yang tercantum dalam Pasal 359 KUHP yang menyatakan sebagai berikut : "Barangsiapa karena kealpaannya menyebabkan matinya orang lain diancam dengan pidana penjara paling lama lima tahun atau kurangan paling lama satu tahun.

Kealpaan mengandung dua syarat, yaitu:

1. Kurang melihat ke depan.

2. Kurang hati-hati yang perlu. ${ }^{32}$

Berdasarkan ketentuan diatas, dapat diikuti dua jalan, yaitu pertama memperhatikan syarat tidak memperkirakan menurut semestinya. Yang kedua memperhatikan syarat tidak berhati-hati atau mewaspadai guna menentukan adanya kealpaan. Siapa saja yang melakukan perbuatan tidak mengadakan kewaspadaan yang semestinya, ia juga tidak mengadakan perkiraan akan terjadi akibat dari kelakuannya. Selanjutnya ada kealpaan yang disadari dan kealpaan yang tidak disadari. Dengan demikian tidak mengadakan perkiraan dan kewaspadaan yang perlu menurut hukum terd iri atas dua kemungkinan yaitu:

1. Terdakwa tidak mempunyai pikiran bahwa akibat yang dilarang mungkin timbul karena perbuatannya.

2. Terdakwa berpikir bahwa akibat tidak akan terjadi ternyata tidak benar.

Kemudian syarat yang ketiga dari pertanggung jawaban pidana yaitu tidak ada alasan pembenar atau alasan yang menghapuskan pertanggung jawaban

${ }^{32}$ Ibid. h. 125 


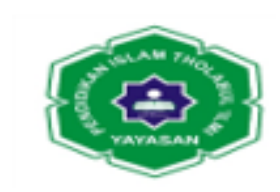

\section{Jurnal Ilmiah METADATA}

pidana bagi si pembuat. $^{23}$ Dalam masalah dasar penghapusan pidana, ada pembagian antara "dasar pembenar" (permisibilry) dan "dasar pemaaf" (ilegal execuse). Dengan adanya salah satu dasar penghapusan pidana berupa dasar pembenar maka suatu perbuatan kehilangan sifat melawan hukumnya, sehingga menjadi legal/boleh, pembuatanya tidak dapat disebut sebagai pelaku tindak pidana. Namun jika yang ada adalah dasar penghapus berupa dasar pemaaf maka suatu tindakan tetap melawan hukum, namun si pembuat dimaafkan, jadi tidak dijatuhi pidana.

Dasar penghapus pidana atau juga bisa disebut alasan-alasan menghilangkan sifat tindak pidana ini termuat di dalam Buku I KUHP, selain itu ada pula dasar penghapus diluar KUHP yaitu : Hak mendidik orang tua wali terhadap anaknya/guru terhadap muridnya dan Hak jabatan atau pekerjaan.

Pengertian perbuatan pidana tidak termasuk hal pertanggungjawab. Perbuatan pidana hanya menunjuk kepada dilarangnya perbuatan. Apakah orang yang telah melakukan perbuatan itu kemudian juga dipidana, tergantung pada soal, apakah dia dalam melakukan perbuatan itu mempunyai kesalahan atau tidak. Jika orang yang melakukan perbuatan pidana itu mempunyai kesalahan, maka tentu dia akan dipidana. Tetapi jika dia tidak mempunyai kesalahan, walaupun dia telah melakukan perbuatan yang terlarang atau tercela, dia tentu tidak dipidana. Asas yang tertulis tidak dipidana jika tidak ada kesalahan, merupakan dasar dari dipidananya si pembuat. ${ }^{33}$

Jadi perbuatan yang tercela oleh masyarakat itu dipertanggung jawabkan pada si pembuatnya. Artinya celaan yang objektif terhad ap perbuatan itukemudian diteruskan kepada si terdakwa. Menjadi soal selanjutnya, apakah si terdakwa juga dicela dengan dilakukannya perbuatn itu. Kenapa perbuatan yang secara objektif tercela itu, secara subjektif dipertangungjawabkan karena musabab dari perbuatan itu adalah diri si pembuatnya.

Dengan mempertanggung jawabkan perbuatan yang tercela itu pada si

${ }^{33}$ Ibid. h. 126 


\section{Jurnal Ilmiah METADATA}

pembuatnya, maka nyatalah bahwa hal dipidana atau tidaknya si pembuat bukanlah bergantung pada apakah ada perbuatan pidana atau tidak, melainkan pada apakah si terdakwa tercela atau tidak karena melakukan perbuatan pidana itu. Karena itulah dikatakan bahwa dasar dari adanya perbuatan pidana adalah asas legalitas yaitu asas yang menentukan bahwa sesuatu perbuatan adalah terlarang dan diancam dengan pidana barangsiapa yang melakukannya, sedangkan dasar dari dipidananya si pembuat adalah asas tidak dipidana jika tidak ada kesalahan.

\section{KESIMPULAN}

Pengguna bahan pangan borax melampaui ambang batas sehingga membahayakan tindak pidana UU No.7 Tahun 1996 Tentang Pangan adalah dengan menggunakan bahan borax untuk tambahan pangan yang dic ampur dengan bakso dan setelah dicampur dengan borax lalu bakso dipasarkan atau dijual kepada konsumen.

Pertanggungjawaban pelaku dalam perkara No. 54/Pid.B/PN.Mdn adalah dengan menjatuhkan hukum kepada pelaku yang menggunakan bahan pangan borax melampaui ambang batas karena perbuatan tersebut telah memenuhi unsurunsur Pasal 10 ayat (1) Jo. Pasal 55 b UU No. 7 Tahun 1996 Tentang Pangan Jo. Pasal 3 ayat (1) Bab III Permenkes No. 722 Tahun 1988.

\section{DAFTAR PUSTAKA}

\section{A. Buku}

Abdul R Saliman, Hukum Bisnis Untuk Perusahaan , Jakarta, Pranada Media Grup, Jakarta, 2005.

Andi Hamzah. Asas-Asas Hukum Pidana. Rineka Cipta, Jakarta,1994.

Adami Chazawi., Pelajaran Hukum Pidana Bagian I, PT. Raja Grafindo Persada, Jakarta, 2000.

Bambang Poernomo. Asas-Asas Hukum Pidana. Ghalia Indonesia, Jakarta, 996

B. Simanjuntak., Pengantar Kriminologi dan Patologi Sosial, Tarsito, Bandung, 1977. 
J.E. Sahetapy, Bunga Rampai Viktimisasi, Eresco, Bandung, 2005.

Mochammad Anwar., Hukum Pidana Bagian Khusus, Alumni, Bandung, 1996.

Mulyatno. Asas-Asas Hukum Pidana, Rineka Cipta, Jakarta, 1993.

Ninik Widiyanti dan Panji Anoraga., Perkembangan Kejahatan dan Masalahnya Ditinjau Dari Aspek Kriminologi dan Sosiologi, PT. Pradnya Paramita, Jakarta, 1986.

R. Soesilo, Kitab Undang-Undang Hukum Pidana, Politea, Bogor, 1998.

R.Wirjono Prodjodikoro, Tindak Pidana Tertentu Dalam KUH.Pidana Indonesia, Eresco, Bandung, 2002.

Romli Atmasasmita, Bentuk-Bentuk Tindak Pidana Yang Dilakukan Oleh Produsen Pada Era Perdagangan Bebas, Mandar Madju, Bandung, 2000.

Ujang Sumarwan. Keamanan Pangan dalam Pola Konsumsi Masyarakat Indonesia, Ghalia Indonesia, Jakarta, 2003.

WA. Bonger., Pengantar Tentang Kriminologi, PT. Pembangunan Ghalia Indonesia, Jakarta, 1982

\section{A. Undang-Undang}

KUH. Pidana R. Soesilo, Politea, Bogor, 1994.

Undang-Undang No. 36 Tahun 2009 Tentang kesehatan

Undang Undang No. 7 Tahun 1996 Tentang Pangan

\section{B. Internet}

www.belajarpsikologi.com/pengertian-kesehatan, diakses tanggal 10 Januari 2013 http://www.makanan mengandung formalin, .minihub.org/direito/txt/2003/22/10direito.html, diakses tanggal 10 Januari 2013 